\title{
ALGAL FLORA OF RICE FIELDS AT EL-KHARGA OASIS, EGYPT
}

\author{
Mohamed A. El-Naghy, Ahmed M. El-Shahed, Adel A. Fathi, and \\ Gamal El Din G. Ahmed \\ Botany Department, Faculty of Science, Minia University, Minia 61519, Egypt
}

\begin{abstract}
Algal flora as well as the physicochemical characteristics of rice fields at ElKharga Oasis was investigated. A total of 99 taxa were identified of which, 23 were Cyanophytes that belong to 11 genera; 19 Chlorophytes belonging to four genera; 52 Bacillariophytes belonging to 15 genera and five Euglenophytes belonging to three genera. Community structure differed among the studied sites diatoms being the most dominant. Taxa that attained high percent of frequency of occurrence (more than $66.6 \%$ i.e. being recorded four times during the study period) include; the blue green algae Osdcillatoria chlabea, O. mougeotii, O. principes, O. raoi, O. simplissima; the green algae Cosmarium lavae var. Lavae, C. pseudopyramidatum and the diatoms Anomoeoneis sphaerophora and Nitzschia thermalis. Taxonomic description for the rarely recorded taxa to the algal flora of rice fields is given. The paper also includes illustrations of 78 recorded algal taxa presented in 6 plates.
\end{abstract}

Key words: Aquatic algal flora, rice fields, El-Kharga Oasis, Egypt.

\section{Introduction}

El-Kharga Oasis belongs to the New Valley governorate which occupies about $67 \%$ of the Western desert and about $45.8 \%$ of Egypt's total area. The New Valley extends over a vast groundwater basin called Dakhla basin which is the main source of water for domestic and agricultural purposes in this area. The climate of the Oasis is extremely arid with an average rainfall below $3.6 \mathrm{~mm} / \mathrm{year}$ and temperature range of 16.1 to $26.3{ }^{\circ} \mathrm{C}$ in winter months and 29 to $39{ }^{\circ} \mathrm{C}$ in summer months (El-Younsy et al., 1991).

Generally, few studies have been performed on algal flora of the Oases in Egypt. Shabaan and El-Habibi (1978) worked on El-Kharga; Shabaan (1985) on Siwa and Kobbia and Shabana (1988) on Bahariya Oasis. Similarly, studies on algae of the whole Egyptian deserts are relatively few. Kobbia and El-Batanouny (1975) studied algal flora of soils from Wadi El-Natroun; El- Awamri et al., (1996) reported on the region of Saint Catherine; and Shaaban and Hamed, (1997) investigated water bodies at El- Arish valley.

Rice fields were chosen for this study since they are considered favourable places for algal growth (De, 1939). Studies on the algal flora in rice fields dealt mostly with the importance of cyanophytes as nitrogen fixers (Brammer, 1983; Hung and Chow, 1988). Such role of algae in soil fertility in rice fields gains more importance and attracts more attention when such fields are 
located in the nitrogen poor desert soils. (Mayland and McIntosh, 1966). Algal crusts of desert range lands may fix about $4 \mathrm{gm} \mathrm{N} / \mathrm{ha}$ after a rainfall (McGregor and Johnson, 1971). The nitrogen fixed by the blue green algae is liberated and then reassimilated by higher plants (Stewart, 1970).

The present work aims at studying the algal flora of rice fields at ElKharga Oasis in an attempt to give information on the role played by these organisms in increasing soil fertility and providing a record on algal flora in this arid region of Egypt, in comparison with that in the Nile valley.

\section{Materials and Methods}

\section{1- Area of Study:}

El-Kharga Oasis is located about $230 \mathrm{~km}$ south of Assiut and $200 \mathrm{~km}$ south west of Qena. The studied area lies between the latitudes $24^{\circ} 30^{\prime}$ and $25^{\circ}$ $00^{\prime} \mathrm{N}$ and the longitudes $30^{\circ} 15^{\prime}$ and $30^{\circ} 28^{\prime} \mathrm{E}$ (Figure 1).

\section{Sampling Sites:}

The studied rice fields were chosen at sites 1,2, 3 indicated on the map (Fig. 1) and each was divided into quadrates of $16 \times 16 \mathrm{~m}$. These fields were submerged with water supplied from water wells through a network of channels. Sites 1, is located in the city, 2 about $10 \mathrm{~km}$ north of the city whereas site 3 lies 15 $\mathrm{km}$ north of the city (Fig.1).

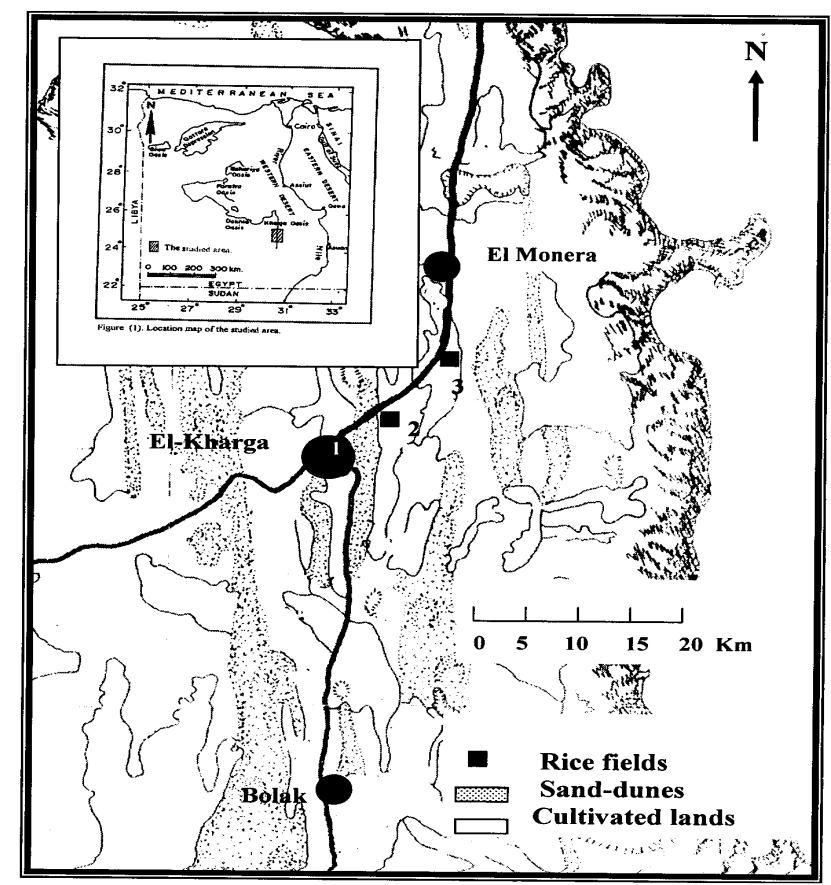

Figure (1): Map Showing the Study Area and the Sampling Sites. 


\section{Sample Collection:}

Samples for physicochemical and algal investigations were collected monthly from good illuminated places in the period June 1998- September 1999 during the cultivation season which extends from June to September. Water samples for physicochemical analysis were collected in one liter polyethylene bottles. Samples for algal investigations were collected, in 0.51 polyethylene bottles from water, water-submerged parts of plants and solid objects embedded in water according to the standard method of Prescott (1982).

\section{2- Physicochemical Characteristics of Water:}

Water Temperature was measured in the field and water samples were transported to the laboratory in a frozen state, kept frozen for later analysis of the rest of parameters. $\mathrm{pH}$ was measured using a $\mathrm{pH}$ meter (Sargent Welch, Scientific Company, London, UK). Conductivity was measured using a conductivity meter (WPA, Saffron Waden, England). Total alkalinity was estimated according to Mackereth et al., (1978) and the chemical oxygen demand was determined according to Golterman et al., (1978). Inorganic soluble orthophosphates and nitrates were measured spectrophotomertically according to Moore and Chapman (1986) using a UV- VIS spectrophotometer (Perkin Elmer mod. 55B, USA). Chlorides were determined according to Jackson, (1960) and silicates according to Mullin and Reily, (1955). Sodium and potassium, were determined according to Golterman et al., (1978) using a flame photometer (M410 Ciba Corning Diagnostics, UK). $\mathrm{Ca}^{2+}$ and $\mathrm{Mg}^{2+}$ were determined by compleximetric methods according to Eaton et al. (1995).

\section{3- Algal Investigations:}

Algal taxa were identified using a Phase contrast Carl Zeiss Med 2 microscope according to the keys of Smith (1950); Desikachary (1959); Rüžička (1977), Komarek and Fott (1983) and Krammer and Lange- Bertalot (1986, 1988, 1991a,b). Illustrations of most of the recorded taxa were performed using a Carl Zeiss Camera Lucida 10X. Diatoms were identified in permanent slides prepared according to Barber and Haworth (1981). Abundance of species was estimated according to the following scale:

$+\quad=$ rare; less than 20 specimens/ 10 microscopic fields,

$++\quad=$ subdominant, $20-40$ specimens/ 10 microscopic fields,

$+++=$ dominant more than 40 specimens $/ 10$ microscopic fields.

\section{Results and Discussions}

\section{I- Physicochemical Characteristics of Water:}

Physicochemical variables of water of the studied rice fields are presented in table (1). The mean annual temperature seems comparatively high than that of water bodies of other parts in Egypt reflecting probably climatic characteristics as located in extremely arid part of Egypt. Water $\mathrm{pH}$ was alkaline (above 8) throughout the period of study, although the $\mathrm{pH}$ in wells which supplied these fields was lower and ranged between 6 and 7 (Elnaghy et al, in press). 
Mohamed A. El-Naghy et al.

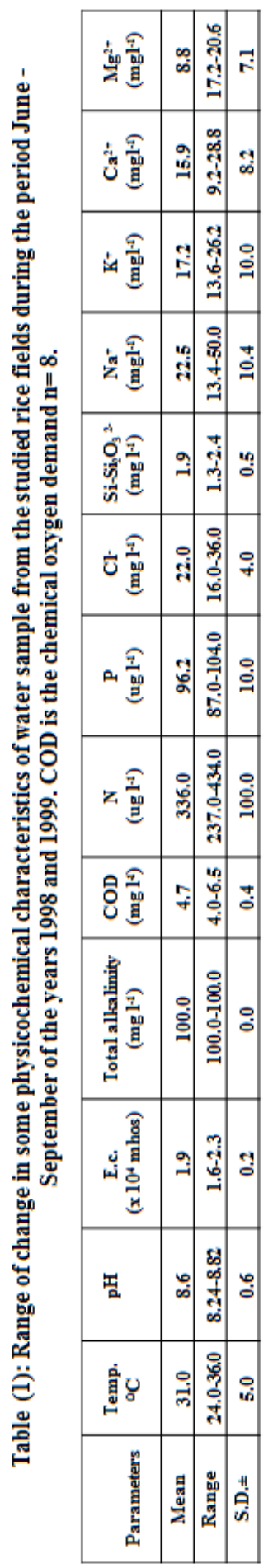


This can be attributed to the metabolic activities of the rice plants grown and to the agricultural practices followed such as fertilization with organic and inorganic fertilizers. The other physicochemical parameters of rice fields water were relatively low when compared with that of the river Nile (Ibrahim, 1997).

\section{II- Structure of The Algal Community at The Study Sites:}

During the period of study, a total of 99 taxa were recorded among which 23 were cyanophytes that belong to 11 genera, 19 chlorophytes that belong to four genera, 52 bacillariophytes that belong to 15 genera and five euglenophytes that belong to three genera (Tab.2). Illustrations of most of these taxa are given in Plates I- VI.

Bacillariophytes were the most dominant group whereas cyanophytes and chlorophytes were the subdominant algae in the area of study. Salama and Kobbia (1982) recorded 51 species of algae from desert soils near Cairo-Alexandria desert road in relation to the edaphic and climatic factors and emphasized that the prokaryotic algae were more abundant and widely distributed in the studied sites (42 species) than eukaryotic members especially diatoms which were recorded as only two species. Kobbia and Shabana, (1988) also reported the dominance of cyanophytes in the algal flora of some cultivated soils at Bahariya Oasis, describing sixty species among which 25 species were cyanophyta with Oscillatoria, Phormidium, Lngbya and Rivularia the dominant genera. Also an account on algal flora of the Mediterranean coast in Egypt was given by ElSheekh et al. (1998). Fifty species of algae were identified from which 42 cyanophyte species among which; Lyngbya hieronymusii, Aphanotheca microspora, Lyngbya birgei, Phormidium inundatum and Oscillatoria tenuis were the most frequent.

During the two seasons of study the total number of taxa was nearly similar except that it was slightly larger in the second season (June, 1999September 1999). Site 3 was richer in number of taxa than the other two sites during both seasons of investigation.

Blue green algae were frequently reported to dominate algal flora of rice fields (Pandey, 1965) whereas in the present study these algae were subdominants which could be explained on the basis that the previous work of Pandy concentrated on planktonic species whereas in this study, both the planktonic and the sessile algae were included. In the present study, cyanophytes were not the most dominant algae although they were present in considerable numbers including the heterocystous, nitrogen- fixing taxa; Anabaena variabilis and Cylindrospermum alatosporum. The presence of nitrogen fixing organisms in rice fields attracted the attention of many investigators towards the use of these organisms in order to reduce the application of nitrogenous fertilizers (Stewart, 1974). Dispersing dried algal flakes in rice fields increased the yield in the range 7-10 kg /ha (Venkataraman, 1972). The Azolla-Anabaena association has been used in many countries as a nitrogen biofertlizer in rice fields. 
Table (2): Occurrence and abundance of algal taxa at the studied sites during the period June - September of the years 1998 and 1999. Marked taxa are those with more than $30 \%$ frequency of occurrence.

\begin{tabular}{|c|c|c|c|c|c|c|c|}
\hline \multirow[b]{2}{*}{ Sites } & \multicolumn{3}{|c|}{1998} & \multicolumn{3}{|c|}{1999} & \multirow{2}{*}{$\begin{array}{c}\text { Index of } \\
\text { frequency } \%\end{array}$} \\
\hline & 1 & 2 & 3 & 1 & 2 & 3 & \\
\hline \multicolumn{8}{|l|}{ Taxa } \\
\hline \multicolumn{8}{|c|}{ Cyanophyta } \\
\hline Achronema macromeres Skuja & & & & & + & + & 25.0 \\
\hline Anabaena variabilis Kütz & & & + & + & + & + & $\mathbf{5 0 . 0}$ \\
\hline A. variabilis f. crassa Woronichin & & & + & + & & + & 37.5 \\
\hline Arthrospira platensis Gomont & & & & + & & & 12.5 \\
\hline Aphanotheca saxicola Naeg. & & & + & & & & $\mathbf{1 2 . 5}$ \\
\hline Chroococcus bitumimsus (Bory.) Hansgirg & & & + & & & & $\mathbf{1 2 . 5}$ \\
\hline C. minutus (Kütz.) Naeg. & + & & & & & & 12.5 \\
\hline C. turgidus (Kütz.) Naeg. & & + & & & & & $\mathbf{1 2 . 5}$ \\
\hline Cyanodictyon endophyticum Pascher & & & + & & & & $\mathbf{1 2 . 5}$ \\
\hline Cylindrospermum alatosporum Frisch * & & ++ & ++ & + & & & 37.5 \\
\hline Gomphosphaeria aponina Kütz. & & & + & & & & 12.5 \\
\hline Microcrois irregularis (Geitler) Kütz. & & & ++ & & & & 12.5 \\
\hline M. hansgergiana (Hansgirg.) Elenkin & & & + & & & & 12.5 \\
\hline Oscillatoria animalis Ag. & & & & + & +++ & ++ & 37.5 \\
\hline O. chlabea (Martenes) Gomont & & + & + & + & + & & $\mathbf{5 0 . 0}$ \\
\hline O. mougeotii Enkin & & + & + & & ++ & & $\mathbf{5 0 . 0}$ \\
\hline O. principes Vaucher & ++ & & ++ & & + & + & $\mathbf{5 0 . 0}$ \\
\hline O. raoi De Toni & & & & + & & & $\mathbf{1 2 . 5}$ \\
\hline O. sancta (Kütz.) Gomont & & + & + & + & + & & $\mathbf{5 0 . 0}$ \\
\hline O. simplissima Gomont & & & + & & & & 12.5 \\
\hline O. subbrevis Schmidle & & ++ & + & ++ & + & + & 62.5 \\
\hline O. terebriformis Ag. & & & & + & & ++ & 25.0 \\
\hline Spirulina spiroliniodes (Ghose) Geitler & & & + & & & & 12.5 \\
\hline \multicolumn{8}{|c|}{ Euglenophyta } \\
\hline Euglena deses v. digrana Ehr. & & & & + & & & 12.5 \\
\hline E. deses v. Intermedia (Klebs) Ehr. & & & + & & & & 12.5 \\
\hline E. hemichromata Skuja & & & + & & & & 12.5 \\
\hline Lepocinclis colligera Deflandre & & & + & & & & 12.5 \\
\hline Phacus curvicauda Hubner & & & + & & & & 12.5 \\
\hline \multicolumn{8}{|c|}{ Chlorophyta } \\
\hline Closterium closteriodes (Ralfs) Louis & & + & + & & & & 25.0 \\
\hline C. ehrenbergii v. Atumidum Grun. & & & + & & & + & 25.0 \\
\hline C. dianae v. dianae Her. & & & + & & & & 12.5 \\
\hline C. lanceolatum v. lanceolatum Kütz. & & & + & & & + & 25.0 \\
\hline C. moniliferum v. Concavum Klebs & & & + & & & & 12.5 \\
\hline Cosmarium hammeri Reinsch & & & & & + & & 12.5 \\
\hline C. hornavanese v. dubovianum ( uto.) Kütz. & & & & & + & & $\mathbf{1 2 . 5}$ \\
\hline C. impressulum Her. & & + & & & & & 12.5 \\
\hline C. lavae v. lavae Rabeh. & + & + & + & & & + & $\mathbf{5 0 . 0}$ \\
\hline C. obtusatum Schmidle & & & + & & + & + & 37.5 \\
\hline C. octodes v. Amoebum W. West & & & + & & + & & 25.0 \\
\hline C. pachydermum Mask & + & & & & & & 12.5 \\
\hline C. pseudopyramidatum Lund & + & & & & & & $\mathbf{1 2 . 5}$ \\
\hline C.punctulatum Kütz. & + & & + & + & + & & $\mathbf{5 0 . 0}$ \\
\hline C. variolatum Kütz. & & & & & & + & 12.5 \\
\hline Pediastrum tetras Ehr. & & & & & + & + & 25.0 \\
\hline Scenedesmus magnus Meyen & & & & & & + & 12.5 \\
\hline
\end{tabular}


Table (2) continue

\begin{tabular}{|c|c|c|c|c|c|c|c|}
\hline \multirow[t]{2}{*}{ Year } & \multicolumn{3}{|c|}{1998} & \multicolumn{3}{|c|}{1999} & \multirow{2}{*}{$\begin{array}{c}\text { Index of } \\
\text { frequency \% }\end{array}$} \\
\hline & 1 & 2 & 3 & 1 & 2 & 3 & \\
\hline \multicolumn{8}{|l|}{ Taxa } \\
\hline S. protuberans v. Donubianus Uherk & & & ++ & & & & 12.5 \\
\hline S. spinosocululatus Chod. & & & + & & & & 12.5 \\
\hline \multicolumn{8}{|c|}{ Bacillariophyta } \\
\hline Anomoeoneis sphaerophora Her. & + & & + & + & + & ++ & 62.5 \\
\hline Caloneis bacillum v. bacillum Grun. & & & & + & & & 12.5 \\
\hline C. pulchra Messikommer & & & & & + & + & 25.0 \\
\hline C. silicula (Her.) Cleve & & & & & & + & 12.5 \\
\hline Cyclotella menegheniana Kütz. & & & & & & + & 12.5 \\
\hline Cymbella minuta Hilse & & + & + & & & ++ & 37.5 \\
\hline C. $\quad$ uso $e$ an (Berkeley) Cleve & & & & + & & + & 25.0 \\
\hline C. pusilla Kütz. & & & & + & & + & 25.0 \\
\hline C. reinhardtii Her. & & + & + & & & & 25.0 \\
\hline Denticula tenuis Kütz. & & & & + & & ++ & 25.0 \\
\hline Eunotia arcus Her. & + & & & & & + & 12.5 \\
\hline E. faba Her. & & & + & & & + & 25.0 \\
\hline E. paralella Ehr. & & & & & & + & 12.5 \\
\hline E. tenella Grun. & & & & & & + & 12.5 \\
\hline Feagilaria tenuicellis Kütz. & & & & & + & + & 25.0 \\
\hline F. ulna (Nitzsch) Lange-Bertalot & & & & & & ++ & 12.5 \\
\hline F. virescens v.capiatata Ostr. & & & & & & + & 12.5 \\
\hline Gomphonema angustatum Kütz. & & & & & & +++ & 12.5 \\
\hline G. gracile Her. & + & & & & & & 12.5 \\
\hline G. lanceolatum Her. & & & + & & & + & 25.0 \\
\hline G. olivaceum (Lyngb.) Kütz. & & & & & & + & 12.5 \\
\hline G. truncatum Her. & + & & & & & & 12.5 \\
\hline Mastigolia elliptica (Ag.) Cleve & & + & & + & & + & 37.5 \\
\hline Meridion circulare Grev. & + & & & & & & 12.5 \\
\hline Navicula capitata v. capitata Ehr. & + & & & & & & 12.5 \\
\hline N. cari v. angusta Grun. & & & + & & & & 12.5 \\
\hline N. confervacea Kütz. & & +++ & & & & + & 25.0 \\
\hline N. $\quad$ uso $e$ an Kütz. & & & & & + & & 12.5 \\
\hline N. cuspidata v. heribaudi M. Perigallo & & & & & + & +++ & 25.0 \\
\hline N. falaisiensis Grun. & & + & & & + & & 25.0 \\
\hline N. gregaria Donk. & + & & & + & & + & 37.5 \\
\hline N. uso $e$ an v. uso $e$ an (Ag) Kütz. & & & & & & + & 12.5 \\
\hline N. pupula v. pupula Kütz. & + & & & & & & 12.5 \\
\hline N. vulpina v. vulpina Kütz. & + & & & & & & 12.5 \\
\hline Nitzschia uso e an Grun. & & & ++ & & & & 12.5 \\
\hline N. angustata (W.Smith) Grun. & & & & + & & + & 25.0 \\
\hline N. compressa (Baily) Boyer & & & + & + & & & 25.0 \\
\hline N. dissipata Kütz. & & & & + & & + & 25.0 \\
\hline N. elegantula Grun. & & & & & + & + & 25.0 \\
\hline N. frustulum Küitz. & & & + & & & + & 25.0 \\
\hline N. linearis (Ag.) W. Smith & & & & & & ++ & 12.5 \\
\hline N. $\quad$ uso $\quad e$ W. Smith & & & & & & + & 12.5 \\
\hline N. palea Kütz. & + & + & & & & + & 37.5 \\
\hline N. solita uso. & & + & & & & & 12.5 \\
\hline N. thermalis Kütz. & + & + & ++ & + & + & + & 75.0 \\
\hline N. umbunata (Ehr.) Lange- Bertalot & & & & & & + & 12.5 \\
\hline N. vivax Hantz. & & & & & + & & 12.5 \\
\hline Pleurosigma strigosum W. Smith & + & & & & & & 12.5 \\
\hline Rhopalodia gibba (Ehr.) O Müll. & & & & & & + & 12.5 \\
\hline
\end{tabular}

Egyptian J. of Phycol. Vol. 5, 2004

- 57 - 
Table (2) continue

\begin{tabular}{|c|c|c|c|c|c|c|c|}
\hline \multirow{2}{*}{ Sites } & \multicolumn{3}{|c|}{1998} & \multicolumn{3}{|c|}{1999} & \multirow{2}{*}{$\begin{array}{c}\text { Index of } \\
\text { frequency } \%\end{array}$} \\
\hline & 1 & 2 & 3 & 1 & 2 & 3 & \\
\hline \multicolumn{8}{|l|}{ Taxa } \\
\hline Surierella ovalis Breb. & & & & & & ++ & 12.5 \\
\hline S. ovata Kütz. & & & + & & & + & 25.0 \\
\hline S. robusta Ehr. & & & & + & & + & 25.0 \\
\hline Number of taxa /site & 18 & 17 & 40 & 23 & 23 & 48 & \\
\hline Total number of taxa & & 59 & & & 66 & & \\
\hline
\end{tabular}

Scale of abundance: $+=$ sporadic (less than 20 specimens / 10 microscopic fields); ++ = subdominant (2040 specimens / 10 microscopic fields); +++ = dominant (more than 40 specimens / 10 microscopic fields).

Although we did not record Azolla in the studid rice fields of El-Kharga Oasis, the occurrence of this aquatic fern in Egypt was reported by Ibrahim and El- Aggan (1993). Azolla has a wide ecological niche of $\mathrm{pH}$ and temperature (Watanabe and Liu, 1992) and if introduced to the area of our study, could possibly survive and grow. It is worth mentioning that the yield of some rice varieties was reported to increase by $18-47 \%$ when Azolla was applied at a rate of $10 \mathrm{t}$ fresh weigh/ ha (Singh, 1977).

The community of green algae of the rice fields was dominated by desmids in spite of the previously reported nature of these organisms as being acidophilic and calciophilic (Hutchinson, 1967). Our results are in agreement with the results of Wolkerling and Gough (1976) who found considerable populations of desmids in the alkaline Wisconsin lake. These authors criticized the hypothesis that relates desmids to acidic, calcium- rich environments.

The recorded taxa agreed in taxonomic description with the diagnoses reported in the used keys of identification (Materials and Methods).

\section{III- Taxonomic Remarks on Some Rarely Recorded Taxa to The Flora of Rice Fields}

Given below are the diagnoses of some taxa that appeared rarely recorded for the algal flora of rice fields in the literature cited, illustrations of these taxa are given in Plates II and III. The morphological features of these organisms agreed with the descriptions outlined in the monographs on desmids (Rüžička, 1977) and chlorococcales (Komarek and Fott, 1983).

\section{Closterium closterioides var closteriodes:}

Cells straight, fusiform, 5-7 times longer than broader. Poles rounded, wall yellowich-brown, chloroplast with about 8 longitudinal ridges and 8 pyrenoides, 260- 270 $\mu \mathrm{m}$ long and 50- 58 $\mu \mathrm{m}$ broad.

Closterium ehrenbergii var atumidum Menegh.:

Cells $165-170 \mu \mathrm{m}$ long and $12-15 \mu \mathrm{m}$ broad, apices rounded, $5 \mu \mathrm{m}$ broad, ventral margin curved, concave without middle portion, wall smooth, chloroplasts with many pyrenoids (5-6) in each semicell. 


\section{Closterium dianae var. dianae :}

Cells strongly curved, gradually attenuated towards the obtusely rounded apices which have an oblique, truncate, thickened dorsal margin, wall smooth, chloroplast with $5-6$ pyrenoids, $167-211 \mu \mathrm{m}$ long and $11-21 \mu \mathrm{m}$ broad.

\section{Closterium moniliferum var concavum :}

Cells crescent-shape, with 9-10 pyrenoids, ventral margin flat, wall finely straight with 5 pyrenoids, apex rounded, cells $205-214 \mu \mathrm{m}$ long and $25-28 \mu \mathrm{m}$ broad, apex $10 \mu$.

\section{Closterium moniliferum var. submoniliferum:}

Cells $207-230 \mu \mathrm{m}$ long, $26-28 \mu \mathrm{m}$ broad, $6 \mu \mathrm{m}$ at the apex, cells strongly curved, ventral margin, slightly concave, wall smooth.

\section{Cosmarium granatum :}

Cells very deeply constricted, sinus linear with a shightly dialated extremity and opening outwords, semicells narrowing, sides rounded, slightly concave, apex slightly obtuse, cell wall densely granulate, with 2 pyrenoids in each semicell. Cells $22-25 \mu \mathrm{m}$ long and $13-18 \mu \mathrm{m}$ broad.

Cosmarium hammeri var hammeri Reins.:

Cells very constricted, sinus linear with a slightly dialated extremity and opening outwords, semicells narrowing rapidly, basal angles rounded, sides slightly concave, apex slightly obtuse, cell wall densely puncatate, the margin attenuates towards the obtuse center of the semicell, cells $30-32 \mu \mathrm{m}$ long and $23 \mu \mathrm{m}$ broad, apex broad, isthmus $7 \mu \mathrm{m}$ thick sinus $5 \mu \mathrm{m}$ deep.

\section{Cosmarium hornavenese var dubsvionum :}

Semicell frustum- shaped, all sides of the cell undulated, each semicell with 6 undulations, a cell has a chloroplast with 2 pyrenoides, chloroplast semicircular, apex straight, sinus $5 \mu \mathrm{m}$, isthmus $10 \mu \mathrm{m}$, cells $30-35 \mu \mathrm{m}$ long and 18- $20 \mu \mathrm{m}$ broad.

\section{Cosmarium impressulum :}

Cells $30-35 \mu \mathrm{m}$ long and $23 \mu \mathrm{m}$ broad, at isthmus $9 \mu \mathrm{m}$ thick, sinus deep and closed, semicells subcircular, with 8 even marginal crenae, the two basal crenae straight, apex obtuse, cells in side and end views broadly elliptic wall often thicker at apex, closely punctate.

\section{Cosmarium laeve var. laeve:}

Cells relatively longer than broader, sinus moderately constricted, semicells widely ovate from the broad base, apex rounded or slightly truncate, wall punctate. Cells $28-30 \mu \mathrm{m}$ long and $20-22 \mu \mathrm{m}$, at isthmus $4 \mu \mathrm{m}$.

\section{Cosmarium octhodes var. amoebum:}

Semicells subcirculr, sinus $15 \mu \mathrm{m}$ and isthmus $17 \mu \mathrm{m}$, cells $60 \mu \mathrm{m}$ long

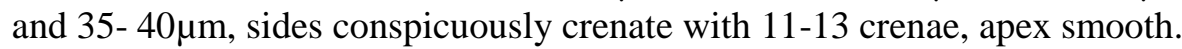




\section{Cosmarium pachydermum var. pachydermum:}

Cells 73-75 $\mu \mathrm{m}$ long and $65 \mu \mathrm{m}$ broad, semicells elliptical with rounded ends and flattened apex, wall smooth, pyrenoid clear appearing in the two semicells, isthmus $30 \mu \mathrm{m}$, sinus linear.

\section{Cosmarium pseudopyramidatum :}

Cell relatively longer than broader, no granules, pyrenoides one in each semicell, apex rounded, sinus deep $7 \mu \mathrm{m}$, cell $40-44 \mu \mathrm{m}$ long and $25-27 \mu \mathrm{m}$, semicells pyramidal, wall punctate, thickened.

Pediastrum tetras Ehr :

Coenobia have 8-16 polygonal cells arranged in a stellate plate, peripheral cells of the colony differ in shape from inner cells, they have one, two or three processes, cell wall smooth.

Scenedesmus alternans Reinsh:

Coenobia are composed of 8 cells, arranged in two alternating rows, cells oval in shape and curved in mid-region, have rounded tips, no spines, cells $7 \mu \mathrm{m}$ long and $5 \mu \mathrm{m}$ broad.

Scenedesmus magnus Meyen :

Coenobia are composed of 4 cells arranged in one row, cells ellipsoidal, swollen in the mid region in terminal cells which have 4 spines, spines $40 \mu \mathrm{m}$ long, cell wall granulate, cells $35-38 \mu \mathrm{m}$ long, $15 \mu \mathrm{m}$ broad.

\section{References}

Barber, G. H. and Haworth, Y. E. (1981). The diatom frustule. Freshwater Biological Association, Scientific publications, 44 Windermere, 113 pp.

Brammer, H. (1983). Agriculture and food production in Poders areas. A case study in Bangaladesh. Water International, 8: 74- 81.

De, P. K. (1939). The role of blue green algae in nitrogen fixation in rice fields. Proc. Roy. Soc., London, 127: 121- 139.

Desikachary, T. V. (1959). Cyanophyta. Monographs on algae. Indian Council of Agriculture Research Publications. New Delhi, 686 pp.

Eaton, A. D.; Clesceri, L. S. and Greenberg, A. E. (eds) (1995). Standard methods for examination of water and wastewater. American Public Health Association Publ., Washington. Sec., 3-57 and 3-75.

El-Awamri, A. A.; Shaaban, A. S. and Hamed A. F. (1996). Algae in Saint Catherine region (South Sinai, Egypt). Egypt. J. Bot.,36 (2): 145- 168.

Elnaghy, M. A.; Fathy A.; El-Shahed A. and Gharib G. (in press). Ecological studies on algae of El-Kharga Oasis. II- Algae of water wells and agricultural drains. Bul. Fac. Sci. Assiut Univ.

El-Sheekh, M. M.; El-Beheiry, M. A. and El-Kady, H. F. (1998). Soil algae of Thymelaea hirustia and Asphodelus microcarpus in Mediterranean Desert of Egypt. Egypt. J. Bot., 38 (1-2): 185-204. 
El-Younsy, A.R.; Mansour H. H.; Ahmed E. A. and Shaheen M. (1991). Lithostratigraphy and structural evaluation of Baris Oasis area, Southwestern Desert, Egypt., Bull. Fac. Sci., Assiut University., (2-F): 193214.

Golterman, H. L.; Clymo, R. S. and Ohnstad M. A. M. (1978). Methods for chemical analysis of freshwaters. Blackwell Scientific Publications, Oxford, 153 pp.

Hung, T. C. and Chow, T. J. (1988). Comparative studies of some nitrogenfixing unicellular cyanobacteria isolated from rice fields. J. gen. Microbiol., 134: 3089- 3097.

Hutchinson, G. E. (1967). A treatise on limnology. II- An introduction to Lake Limnoplankton. John Wiley \& Sons. Inc. New York. 1116pp.

Ibrahim, H. (1997). Monitoring eutrophication at some localities of the Nile system using algae as indicators. M.Sc. Thesis, Faculty of Science, Minia Univ. Egypt.

Ibrahim M. D. and El- Aggan W. (1993). On the occurrence of the water fern Azolla mexicana in Egypt. Bull. Fac. Sci. Alexandria Univ., 33(A): 44- 54.

Jackson, M. L. (1960). Soil Chemical analysis Constable and Co London. pp. 261-262.

Kobbia, I. A. and El- Batanony, K. H. (1975). Studies on algal flora of Egyptian soils. I- Different sites along a lake in salines of Wadi El-Natrun. Bull. Cairo Univ. Herb., 6: 61- 72.

Kobbia, I. M. and Shabana, E. F. (1988). Studies on the soil algal flora of Egyptian Bahariya Oasis. Egypt. J. Bot., 31 : 23-43.

Komarek, J. and Fott, B. (1983). Chlorophyceae, Ordung: Chlorococcales. In: das Phytoplankton des Susswassers. Systematik und Biologie, Teil 7, Stuttguart, 1044pp.

Krammer, K. and Lange-Bertalot, H. (1986). Bacillariophyceae 1- Teil: Naviculaceae. In: Süßwasserflora von Mittleuropa 2/1, VEB Gustav Fischer Verlag, Jena 876 pp.

Krammer, K. and Lange-Bertalot, H. (1988): Bacillariophyceae 2- Teil: Bacillariaceae, Epithemiaceae, Surirellaceae. In: Süßwasserflora von Mittleuropa 2/2, VEB Gustav Fischer Verlag, Jena 596 pp.

Krammer, K. and Lange-Bertalot, H. (1991a). Bacillariophyceae 3- Teil: Centrales, Fragilariaceae, Eunotiaceae. In: Süßwasserflora von Mittleuropa 2/3, VEB Gustav Fischer Verlag, Jena 575 pp.

Krammer, K. and Lange-Bertalot H. (1991b). Bacillariophyceae 4- Teil: Achnanthaceae, kritische Ergänzungen zu Navicula (Lineolatae) und Gomphonema Gesamtliteraturverzeichnis Teil 1-4. In: Süßwasserflora von Mittleuropa 2/1, VEB Gustav Fischer Verlag, Jena 876 pp.

Mackereth, F. J. H.; Heron, J. and Talling, J. F. (1978). Water analysis: Some methods for limnologists. Freshwater Biol. Assc. Sci. Publ., No. 36. 
Mayland, H. F. and McIntosh, T. M. (1966). Distribution of nitrogen fixed in desert desert algal crust. Soil Sci. Soc. Amer. Proc., 30: 606- 609.

McGregor, A. W. and Johnson, D. E. (1971). Capacity of desert algal crusts to fix atmospheric nitrogen. Soil Sci. Soc. Amer. Proc., 35: 843- 844.

Moore P. D. and Chapman, S. B. (1986): Methods in plant ecology. Blackwell Sci. Publ. Oxford, 331 pp.

Mullin, I. B. and Reily, I. P. (1955). The colorimetric determination of silicate with special reference to sea and natural waters. Anal. Chem. Acta, 12: 162176.

Pandey, D. C. (1965). A study on the algae from Paddy fields of Ballia snd Ghazipur districts of Uttar Pradesh, India. Nova Hedwigia, 10 (1/2), 177223.

Prescott, G.W. (1982). How to know the fresh water algae., Wm.C. Brown Company Publishers Dubuque Iowe., 293pp.

Rüžička, J. (1977). Die Desidiacean Mitteleuropas. Band 1. E. Schweizerbart'sche Verlagbuchhandlung, Stuttguart., 335pp.

Salama, A. M and Kobbia, I. A.(1982). Studies on the algal flora of Egyptian soils : II - Different sites of a sector in the Libyan Desert, Egypt . J. Bot., $25,139$.

Shaaban, A. S. (1985). The algal flora of Egyptian Oasis. II- On the algae of Siwa Oasis. Bull. Desert d' Egypte, 28: 1-4.

Shaaban, A. S. and El-Habibi, A. (1978). The algal flora of Egyptian Oasis. IThe algal flora of Kharga Oasis. Bull. Desert, d'Egypte, 28. 1-4.

Shaaban, A. M. and Hamed, A. F. (1997). Freshwater algae of El- Arish Valley and its vicinity, North Sinai, Egypt. The desert Inst. Bull., Egypt,47(1): 101- 118.

Singh, P. K. (1977). Effect of Azolla on the yield of paddy with and without the application of nitrogen fertilizer. Curr. Sci., 46: 642- 644.

Smith, G.M. (1950). The fresh water algae of the united states. 2nd. ed. - New York, Mo Grow. Hill book Co., 719.

Stewart, W. D. P. (1970). Algal fixation of atmospheric nitrogen. Plant and Soil, 32: 55- 88.

Stewart, W. D. P. (1974). Blue green algae. In Biology of nitrogen fixation. (ed. A. Quispel) Amsterdam, pp. 202- 287.

Venkataraman, G. S. (1972). Algal Biofertilizers and Rice Cultivation. Today and Tomorrow's Printers and Publishers, New Delhi.

Watanabe, I and Liu, C. C. (1992). Improving nitrogen- fixed systems and integrating them into sustainable rice farming. Dev. Plant Soil Sci., 49: 5767.

Wolkerling, W. J. and Gough, S. B. (1976). Wisconsin desmids. III- Desmid community composition and distribution in relation to lake type and water chemistry. Hydrobiol. 51 (1): 3- 32. 
PLATE (I)

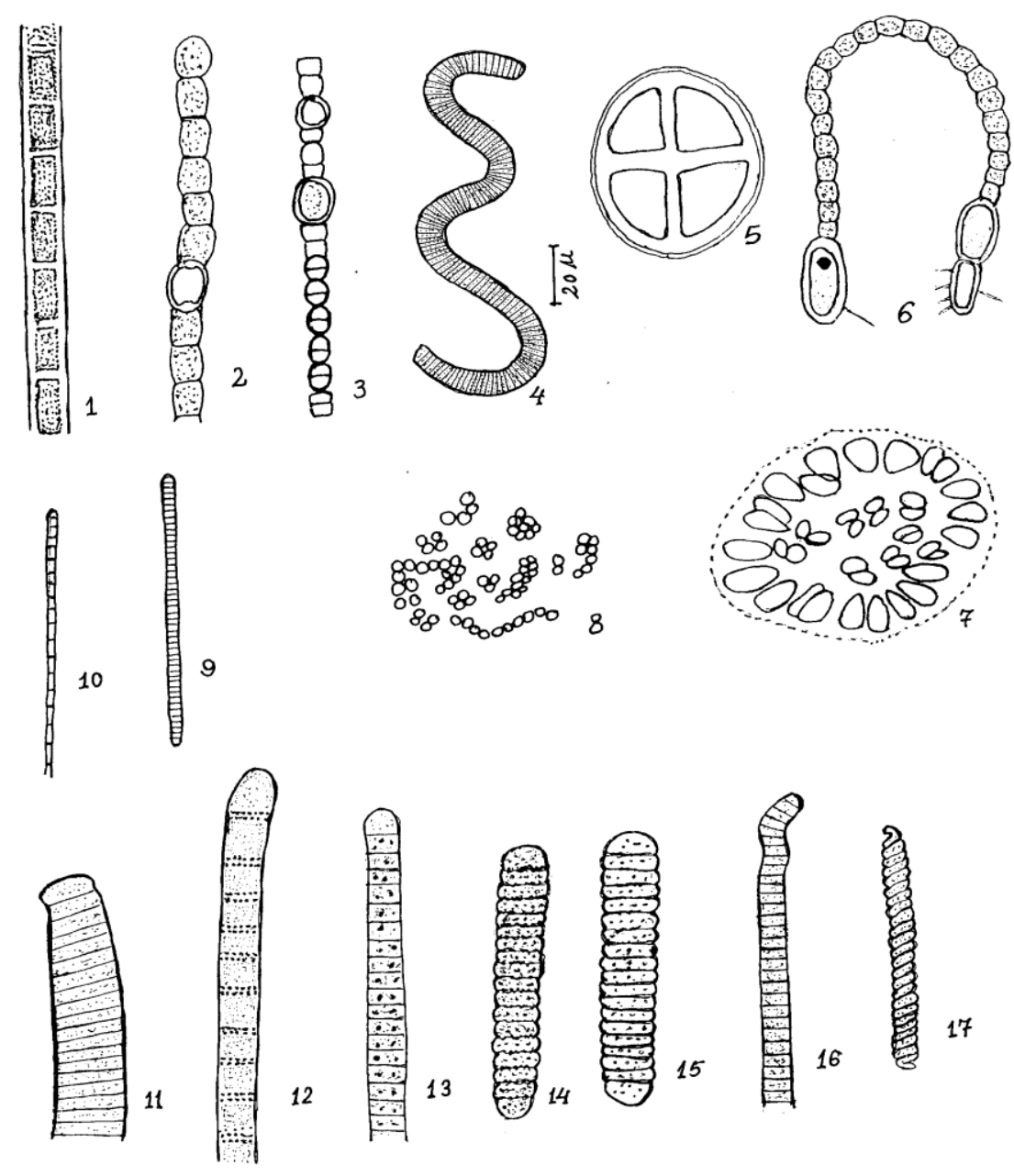

Figures (1-17): 1- Achronema macromeris, 2- Anabaena variabilis,

3- A variabilis f. crassa, 4- Arthrospira platensis, 5-Chroococcus turgidus, 6- Cylindrospermum. alatosporum,- 7- Gomphosphaeria aponica,

8- Microcystis hansgirgiana, 9- Oscillatoria animalis, 10- O. chlabea, 11- O. principes, 12- $O$. raoi, 13- O. sancta, 14- O. simplissima, 15- O. subbrevis, 16- O. terebriformis, 17- Spirulina spirulinioides.

$10 \mu=9.0 \mathrm{~mm}$ if not otherwise indicated. 


\section{PLATE (II)}

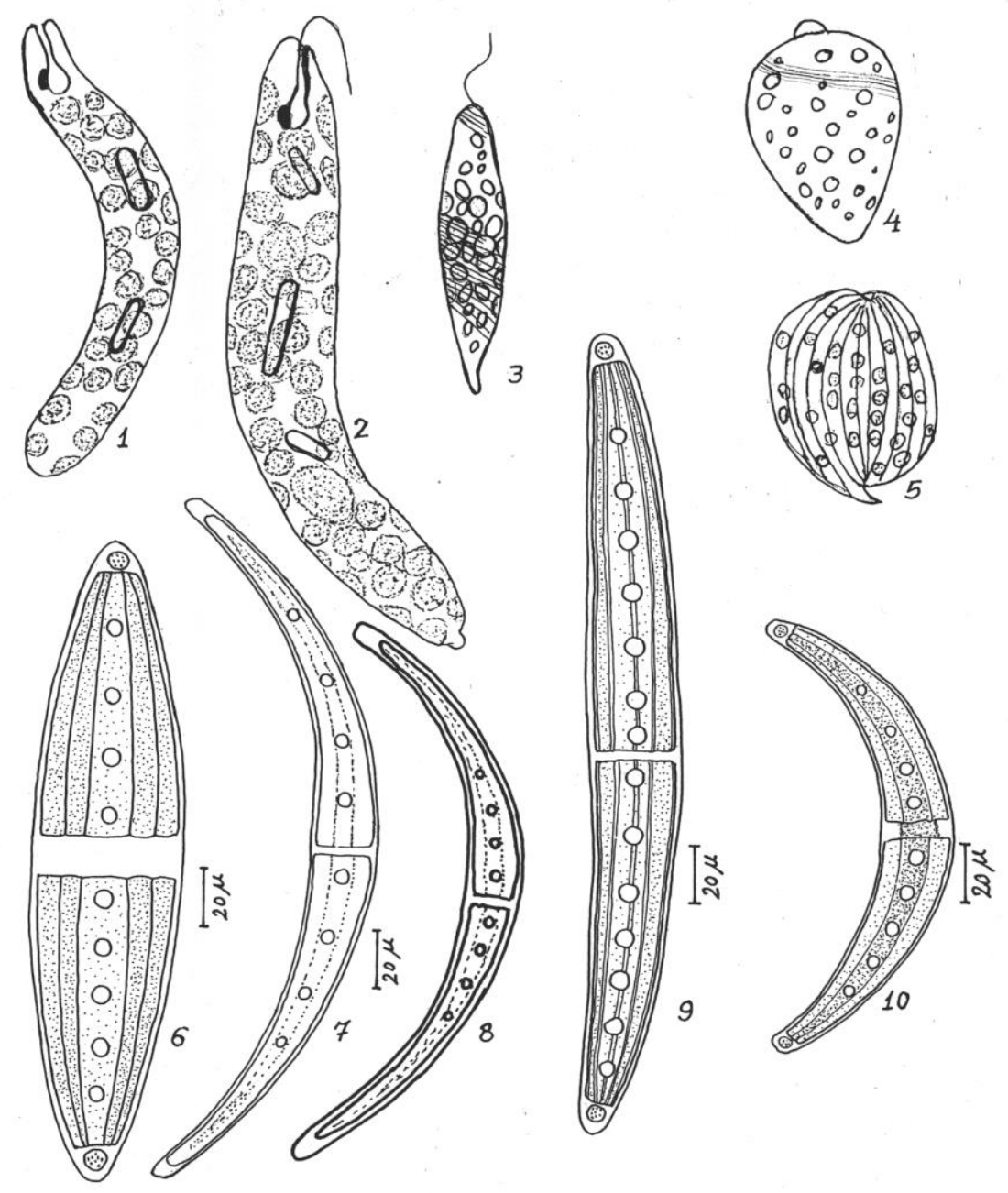

Figures (1-10): 1- Euglena deses v. digrana, 2-E.deses v. intermedia, 3- E. hemichromata, 4- Lepocinclis colligera, 5- Phacus curvicauda, 6- Closterium closteriodes, 7- C. ehrenbergii v. atumidum, 8- C. dianae v. dianae, 9- C. lanceolatum v. lanceolatum, 10- C. moniliferum v. concavum. $10 \mu=9.0 \mathrm{~mm}$ if not otherwise indicated. 


\section{PLATE (III)}

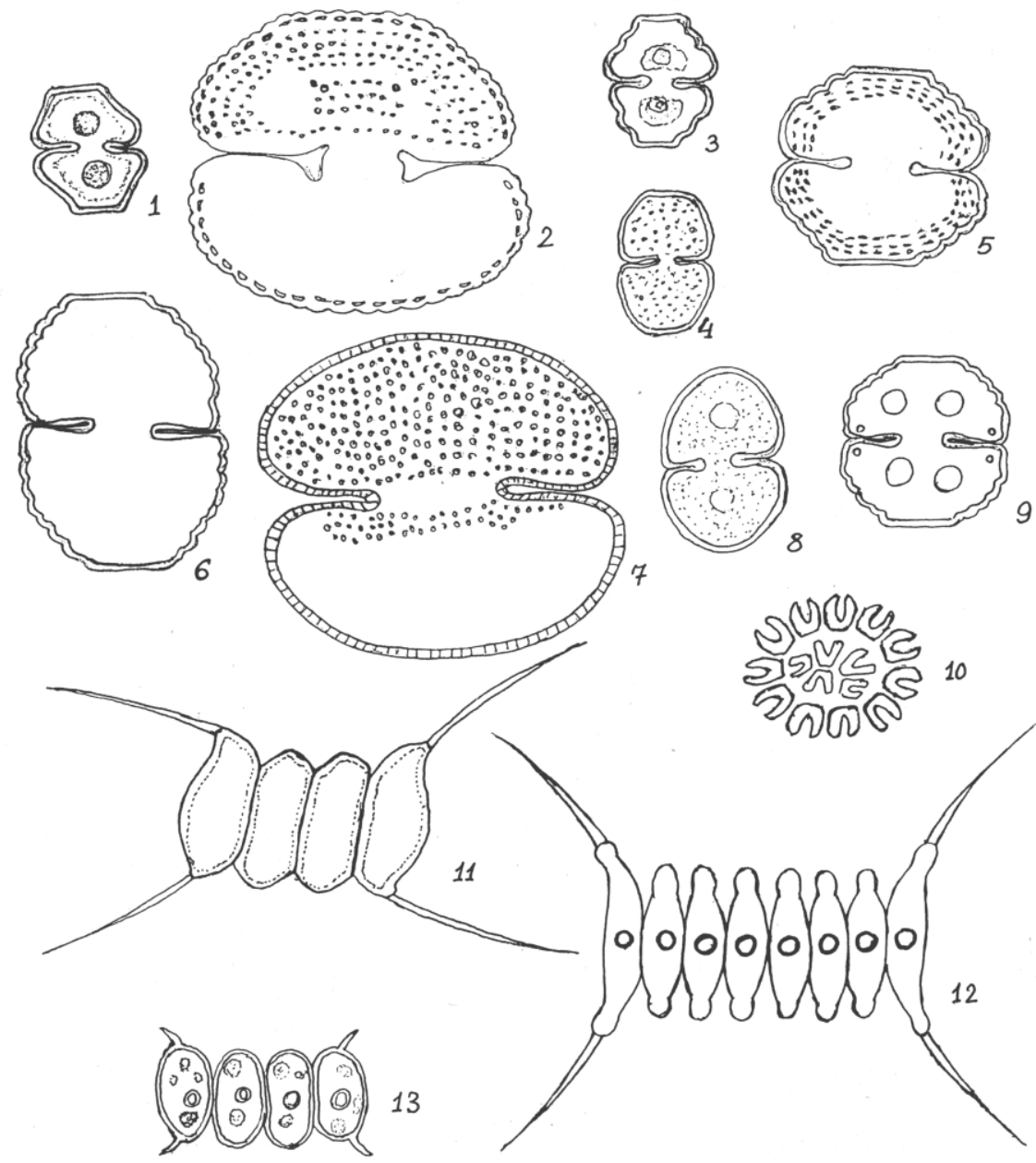

Figures (1-13): 1- Cosmarium hammeri, 2- C. hornavanese v. dubovianum, 3- C. impressulum, 4- C. lavae v. lavae, 5- C. obtusatum, 6- C. octodes v. amoebum, 7-C. pachydermum, 8- C. pseudopyramidatum, 9- C. punctulatum, 10- Pediastrum tetras, 11- Scenedesmus magnus, 12-S. opoliensis, 13- S. spinosoacululatus.

$10 \mu=9.0 \mathrm{~mm}$ if not otherwise indicated 
PLATE (IV)

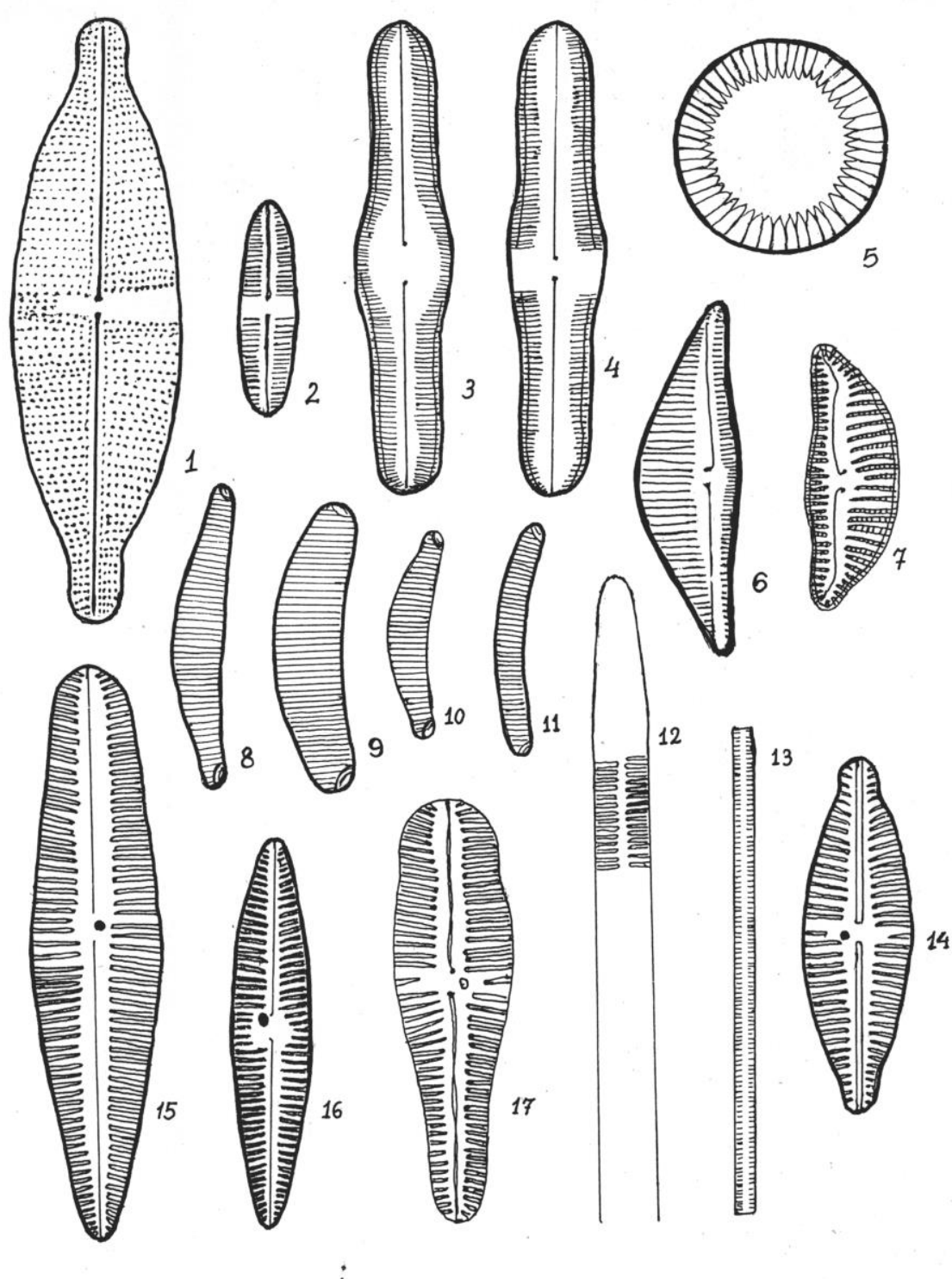

Figures (1-17): 1- Anomoeoneis sphaerophora, 2-Caloneis bacillum v. bacillum,

3- C. pulchra, 4- C. silicula, 5-Cyclotella menegheniana, 6-Cymbella minuta,

7- C. prostrata, 8- Eunotia arcus, 9- E. faba, 10- E. pectinalis v. minor, 11- E. tenella, 12- Feagilaria ulna, 13- F. virescens v. capiatata, 14- Gomphonema angustatum, 15- G. gracile, 16- G. olivaceum, 17- G. truncatum. $10 \mu=20 \mathrm{~mm}$ if not otherwise indicated. 


\section{PLATE (V)}

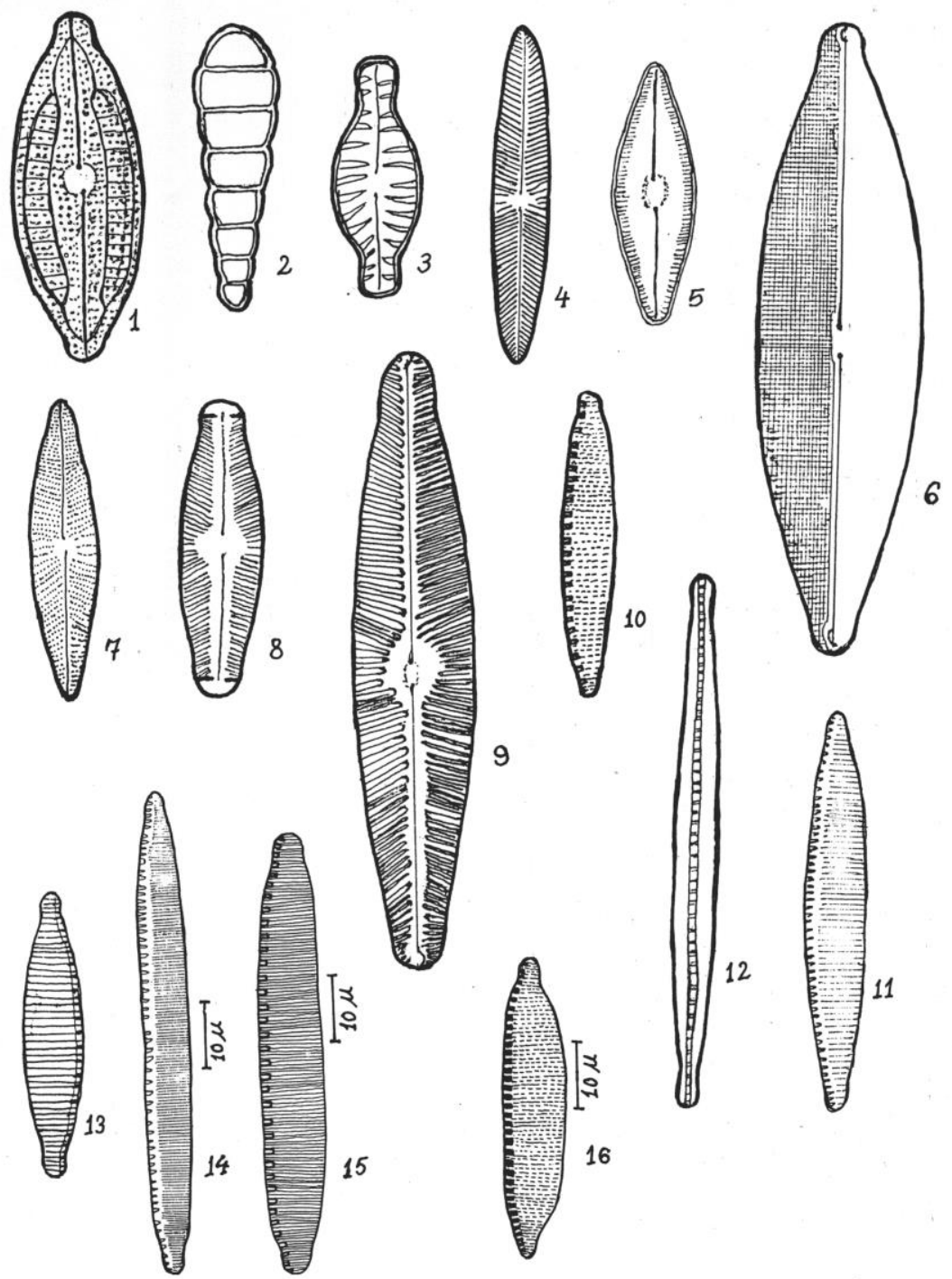

Figures (1-16): 1- Mastigolia elliptica, 2-Meridion circulare,

3- Navicula capitata v. capitata, 4- $N$. cari v. angusta, 5- N. confervacea,

6- $N$. cuspidata, 7- N. lanceolata v. lanceolada,8- N. pupula v. pupula,

9- $N$. vulpina v. vulpina, 10 - Nitzschia amphibia, 11- Nitzschia angustata, 12- N. dissipata, 13- N. frustulum, 14- N. linearis, 15- N. umbunata, 16- N. vivax. $10 \mu=20 \mathrm{~mm}$ if not otherwise indicated. 


\section{PLATE (VI)}
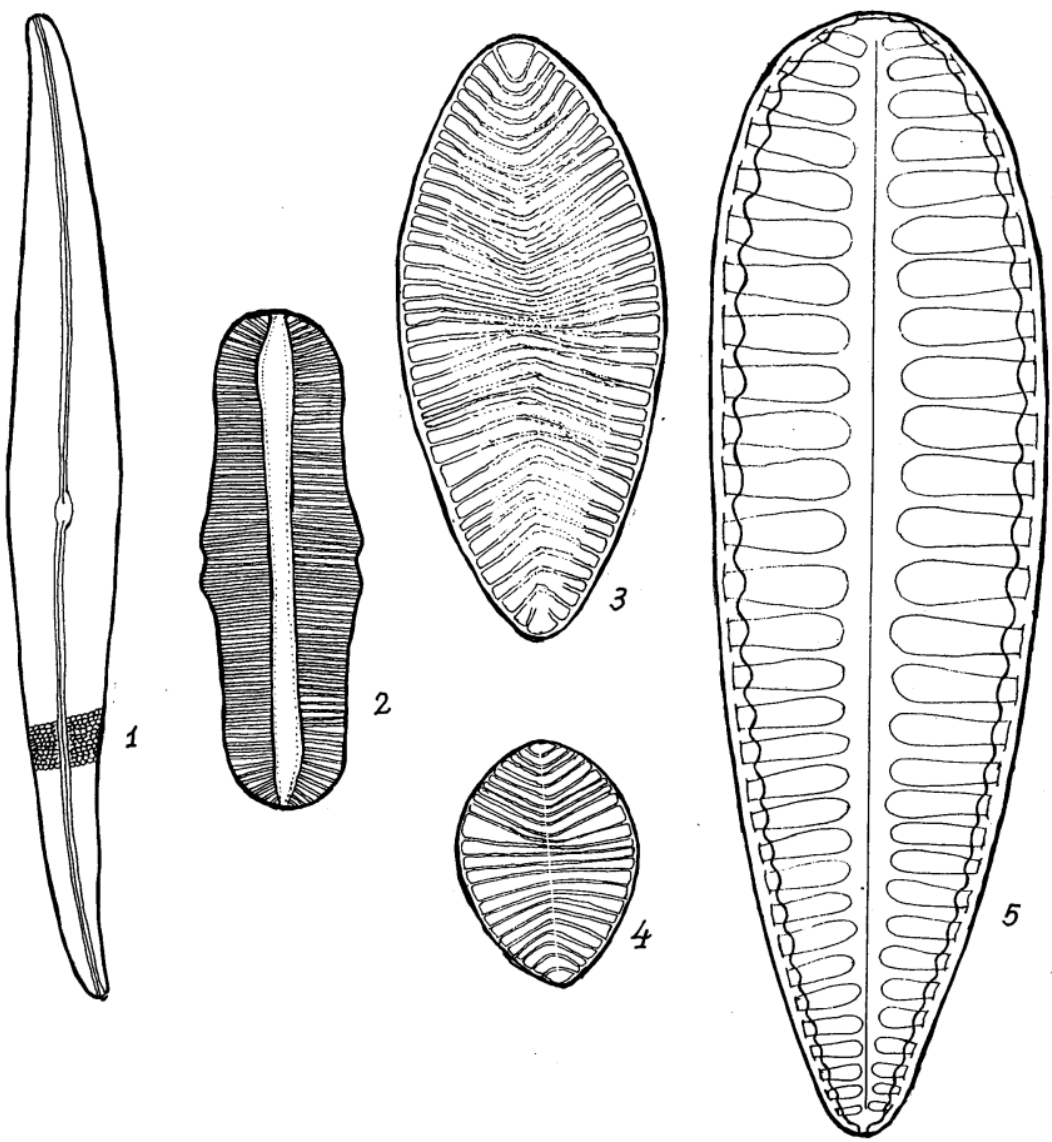

Figures (1-5): 1- Pleurosigma strigosum, 2 - Rhopalodia gibba, 3- Surierella ovalis, 4- S. ovata, 5- S. robusta.

$1 \mu=1.2 \mathrm{~mm}$. 


\title{
القلورا الطحلبية فى مزارع الأرز بواحـة الخارجـة بمصـر. \\ محمد عبد الوهاب الناغى وأحمد الشاهد وعادل أحمد فتحى وجمال الدين غريب أحمد

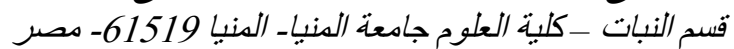

\begin{abstract}
تناول البحث دراسة الفلورا الطحلبية والخصائص الفيزيوكيميائية لمزارع الأرز بواحة الخارجة التابعة لمحافظة

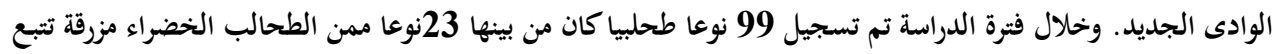

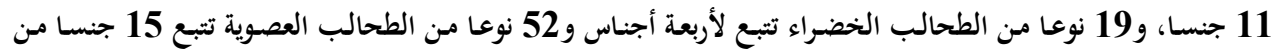

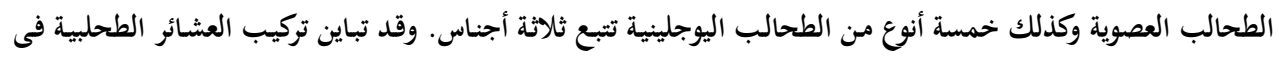

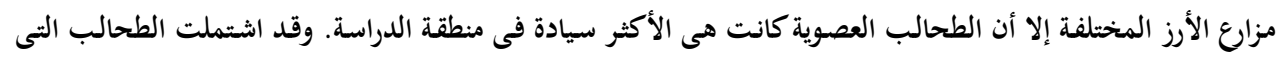

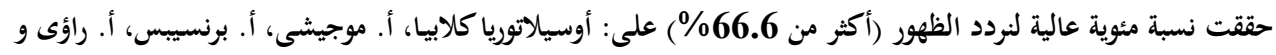

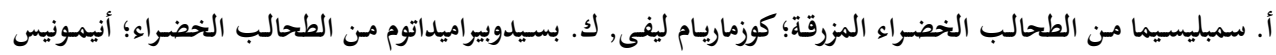

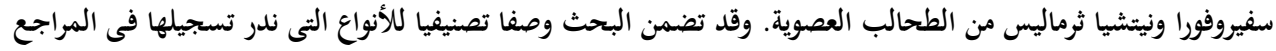

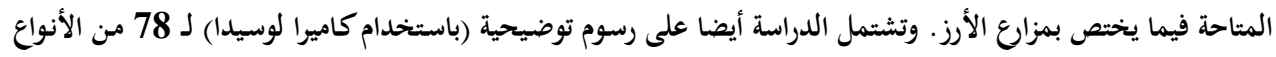
التى تم تسجيلها مدرجة فى ست لوحات.
\end{abstract}

